\title{
Dental treatment considerations in the chemotherapy patient
}

\author{
Begonya Chaveli López, Carmen Gavaldá Esteve, Mª Gracia Sarrión Pérez.
}

Valencia University Dental School, Valencia, Spain

Correspondence:

Apdo. de correos 24

46740 Carcaixent, Valencia, España

E-mail: begonya_chaveli@hotmail.com

Chaveli López B, Gavaldá Esteve C, Sarrión Pérez MG. Dental treatment considerations in the chemotherapy patient. J Clin Exp Dent. 2011;3(1):e31-42.

http://www.medicinaoral.com/odo/volumenes/v3i1/jcedv3i1p31.pdf

Article Number: $50318 \quad$ http://www medicinaoral.com/odo/indice.htm

(C) Medicina Oral S. L. C.I.F. B 96689336 - eISSN: 1989-5488

eMail: jced@jced.es

\begin{abstract}
Cancer patients can suffer oral toxic effects secondary to antineoplastic therapy in the form of radiotherapy and/ or chemotherapy. This risk is conditioned by a range of factors, including the high cell turnover rate of the oral mucosa, the diversity and complexity of the oral microflora, and soft tissue trauma during normal oral function. The present study offers a literature review of the main oral complications secondary to chemotherapy, and describes the different options for dental treatment before, during and after oncological treatment, published in the scientific literature. To this effect a PubMed-Medline ${ }^{\circledR}$ search was made using the following keywords: chemotherapy, cancer therapy, dental management, oral mucositis, neurotoxicity, intravenous bisphosphonates and jaw osteonecrosis. The search was limited to human studies published in the last 10 years in English or Spanish. A total of 50 articles were identified: 17 research papers, 25 reviews, 6 letters to the Editor, and two clinical guides developed by expert committees. The data obtained showed the main oral complications of chemotherapy to be mucositis, neurotoxicity, susceptibility to infections, dental, salivary and taste alterations, and the development of osteonecrosis. Based on the reviewed literature, elective dental treatment can be provided before chemotherapy, with emphasis on the elimination of infectious foci. During chemotherapy, dental treatment should be limited to emergency procedures, while dental treatment of any kind can be prescribed after chemotherapy - with special considerations in the case of patients who have received treatment with intravenous bisphosphonates.
\end{abstract}

Key words: Chemotherapy, cancer treatment, dental treatment, oral mucositis, neurotoxicity, jaw osteonecrosis, intravenous bisphosphonates. 


\section{Introduction}

Anticancer chemotherapy currently involves the use of drugs (cytostatic or cytotoxic agents) that avoid proliferation of the tumor cells and/or cause their destruction, taking advantage of the characteristically shortened cell cycle of these cells. The main problem posed by such treatment is the lack of selectivity of most antineoplastic drug substances, since they also act upon normal cells with an accelerated cell cycle, such as bone marrow cells, hair follicle cells and the epithelial cells of the gastrointestinal tract (1). The chemotherapeutic agents most commonly used in head and neck malignancies are bleomycin, cisplatin, methotrexate, 5-fluorouracil, vinblastine and cyclophosphamide (2).

\section{Etiopathogenesis: cytostatic drug toxicity}

Antineoplastic drugs can act upon the different tissues either directly or indirectly. The direct side effects of such drugs start with the primary oral tissue damage caused by their indiscriminate effect upon the cell replication cycle, such as for example in the oral mucosa, where these cytotoxic agents destroy the proliferating basal

\begin{tabular}{|c|c|c|c|c|}
\hline AUTHOR & ARTICLE NAME & JOURNAL & YEAR & $\begin{array}{l}\text { TYPE OF } \\
\text { ARTICLE } \\
\end{array}$ \\
\hline Hejna et al. & $\begin{array}{l}\text { Decrease of duration and symptoms in chemotherapy-induced oral mucositis by topical } \\
\text { GM-CSF: results of a prospective randomised trial. }\end{array}$ & Eur J Cancer. & 2001 & $\mathrm{RCT}$ \\
\hline Minicucci et al. & $\begin{array}{l}\text { Dental abnormalities in children after chemotherapy treatment for acute lymphoid } \\
\text { leukemia. }\end{array}$ & Leuk Res. & 2003 & Case series \\
\hline Grunberg et al. & Incidence of chemotherapy-induced nausea and emesis after modern antiemetics. & Cancer. & 2004 & Cohort \\
\hline Marx et al. & $\begin{array}{l}\text { Bisphosphonate-induced exposed bone (osteonecrosis/osteopetrosis) of the jaws: risk } \\
\text { factors, recognition, prevention, and treatment. }\end{array}$ & $\begin{array}{l}\text { J Oral } \\
\text { Maxillofac } \\
\text { Surg. }\end{array}$ & 2005 & Case series \\
\hline $\begin{array}{l}\text { Sepúlveda } \\
\text { et al. }\end{array}$ & $\begin{array}{l}\text { Oral ulcers in children under chemotherapy: clinical characteristics and their relation with } \\
\text { Herpes Simplex Virus type } 1 \text { and Candida Albicans. }\end{array}$ & $\begin{array}{l}\text { Med Oral Patol } \\
\text { Oral Cir Bucal. }\end{array}$ & 2005 & $\begin{array}{l}\text { Cross- } \\
\text { sectional }\end{array}$ \\
\hline Bamias et al. & $\begin{array}{l}\text { Osteonecrosis of the jaw in cancer after treatment with bisphosphonates: incidence and } \\
\text { risk factors. }\end{array}$ & $J$ Clin Oncol. & 2005 & Case series \\
\hline \begin{tabular}{|l|} 
López-Galindo \\
et al.
\end{tabular} & $\begin{array}{l}\text { Clinical evaluation of dental and periodontal status in a group of oncological patients } \\
\text { before chemotherapy. }\end{array}$ & \begin{tabular}{|l|} 
Med Oral Patol \\
Oral Cir Bucal.
\end{tabular} & 2006 & Case-control \\
\hline Marx et al. & $\begin{array}{l}\text { Oral bisphosphonate-induced osteonecrosis: risk factors, prediction of risk using serum } \\
\text { CTX testing, prevention, and treatment. }\end{array}$ & \begin{tabular}{|l|} 
Oral \\
Maxillofac \\
Surg.
\end{tabular} & 2007 & Case series \\
\hline Antunes et al. & $\begin{array}{l}\text { The Impact of low power laser in the treatment of conditioning-induced oral mucositis: A } \\
\text { report of } 11 \text { clinical cases and their review. }\end{array}$ & $\begin{array}{l}\text { Med Oral Patol } \\
\text { Oral Cir Bucal. }\end{array}$ & 2008 & Case series \\
\hline Hueso et al. & Chemotherapy-induced acral erythema: a clinical and histopathologic study of 44 cases & \begin{tabular}{|l|} 
Actas \\
Dermosifiliogr. \\
\end{tabular} & 2008 & Case series \\
\hline $\begin{array}{l}\text { Boonyapakorn } \\
\text { et al. }\end{array}$ & $\begin{array}{l}\text { Bisphosphonate-induced osteonecrosis of the jaws: prospective study of } 80 \text { patients with } \\
\text { multiple myeloma and other malignancies. }\end{array}$ & Oral Oncol. & 2008 & Cohort \\
\hline Jensen et al. & $\begin{array}{l}\text { Oral mucosal lesions, microbial changes, and taste disturbances induced by adjuvant } \\
\text { chemotherapy in breast cancer patients. }\end{array}$ & \begin{tabular}{|l|} 
Oral Surg \\
Oral Med Oral \\
Pathol Oral \\
Radiol Endod.
\end{tabular} & 2008 & Case-control \\
\hline $\begin{array}{l}\text { Ripamonti } \\
\text { et al. }\end{array}$ & $\begin{array}{l}\text { Decreased occurrence of osteonecrosis of the jaw after implementation of dental } \\
\text { preventive measures in solid tumour patients with bone metastases treated with } \\
\text { bisphosphonates. The experience of the National Cancer Institute of Milan. }\end{array}$ & Ann Oncol. & 2009 & Case series \\
\hline Bagan et al. & $\begin{array}{l}\text { Osteonecrosis of the jaws by intravenous bisphosphonates and osteorradionecrosis: a } \\
\text { comparative study. }\end{array}$ & Med Oral. & 2009 & Case series \\
\hline $\begin{array}{l}\text { Dimopoulos } \\
\text { et al. }\end{array}$ & $\begin{array}{l}\text { Reduction of osteonecrosis of the jaw (ONJ) after implementation of preventive measures } \\
\text { in patients with multiple myeloma treated with zoledronic acid. }\end{array}$ & Ann Oncol. & 2009 & $\begin{array}{l}\text { Practice } \\
\text { Guideline }\end{array}$ \\
\hline Colella et al. & $\begin{array}{l}\text { Efficacy of a spray compound containing a pool of collagen precursor synthetic } \\
\text { aminoacids (1-proline, l-leucine, 1-lysine and glycine) combined with sodium } \\
\text { hyaluronate to manage chemo/radiotherapy-induced oral mucositis: preliminary data of an } \\
\text { open trial. }\end{array}$ & $\begin{array}{l}\text { Int } J \\
\text { Immunopathol } \\
\text { Pharmacol. }\end{array}$ & 2010 & Clinical Trial \\
\hline Hasmim et al. & $\begin{array}{l}\text { Zoledronate inhibits endothelial cell adhesion, migration and survival through the } \\
\text { suppression of multiple, prenylation-dependent signaling pathways. }\end{array}$ & $\begin{array}{l}\text { J Thromb } \\
\text { Haemost. }\end{array}$ & 2007 & Clinical Trial \\
\hline Campisi et al. & $\begin{array}{l}\text { Bisphosphonate-related osteonecrosis of the jaw (BRONJ): run dental management } \\
\text { designs and issues in diagnosis. }\end{array}$ & Ann Oncol. & 2007 & \begin{tabular}{|l|l|} 
Practice \\
Guideline
\end{tabular} \\
\hline Bagán et al. & $\begin{array}{l}\text { Recomendaciones para la prevención de la osteonecrosis de los maxilares (ONM) en } \\
\text { pacientes con cáncer tratados con bisfosfonatos intravenosos. }\end{array}$ & \begin{tabular}{|l|} 
Med Oral Patol \\
Oral Cir Bucal.
\end{tabular} & 2008 & \begin{tabular}{|l|} 
Practice \\
Guideline
\end{tabular} \\
\hline Bunetel et al. & $\begin{array}{l}\text { Oral pathoses caused by Candida albicans during chemotherapy: update on development } \\
\text { mechanisms. }\end{array}$ & \begin{tabular}{|l|} 
Oral Surg \\
Oral Med Oral \\
Pathol Oral \\
Radiol Endod.
\end{tabular} & 1996 & Review \\
\hline
\end{tabular}




\begin{tabular}{|c|c|c|c|c|}
\hline \begin{tabular}{l|l} 
Raber- \\
Durlacher et al.
\end{tabular} & Periodontal infection in cancer patients treated with high-dose chemotherapy. & $\begin{array}{l}\text { Support Care } \\
\text { Cancer. }\end{array}$ & 2002 & Review \\
\hline Epstein et al. & $\begin{array}{l}\text { The role of salivary function in modulating chemotherapy-induced oropharyngeal } \\
\text { mucositis: a review of the literature. }\end{array}$ & $\begin{array}{l}\text { Oral Surg } \\
\text { Oral Med Oral } \\
\text { Pathol Oral } \\
\text { Radiol Endod. }\end{array}$ & 2002 & Review \\
\hline Donnelly et al. & Antimicrobial therapy to prevent or treat oral mucositis. & $\begin{array}{l}\text { Lancet Infect } \\
\text { Dis. }\end{array}$ & 2003 & Review \\
\hline \begin{tabular}{l|l} 
Caribé-Gomes \\
et al.
\end{tabular} & Dental management of the complications of radio and chemotherapy in oral cancer. & Med Oral. & 2003 & Review \\
\hline Barasch et al. & Risk factors for ulcerative oral mucositis in cancer patients: unanswered questions. & Oral Oncol. & 2003 & Review \\
\hline Clarkson et al. I & Interventions for treating oral candidiasis for patients with cancer receiving treatment. & $\begin{array}{l}\text { Cochrane } \\
\text { Database Syst } \\
\text { Rev. }\end{array}$ & 2004 & Review \\
\hline \begin{tabular}{|l|} 
Jimenez- \\
Soriano et al.
\end{tabular} & Bisphosphonates, as a new cause of drug-induced jaw osteonecrosis: An update. & \begin{tabular}{|l|} 
Med Oral Patol \\
Oral Cir Bucal.
\end{tabular} & 2005 & Letter \\
\hline Stone et al. & Management of oral mucositis in patients with cancer. & \begin{tabular}{|l|} 
Eur J Oncol \\
Nurs.
\end{tabular} & 2005 & Review \\
\hline Migliorati et al. & $\begin{array}{l}\text { Managing the care of patients with bisphosphonate-associated osteonecrosis: an American } \\
\text { Academy of Oral Medicine position paper. }\end{array}$ & $\begin{array}{l}J \text { Am Dent } \\
\text { Assoc. }\end{array}$ & 2005 & Review \\
\hline \begin{tabular}{|l|l|}
$\begin{array}{l}\text { López-Castaño } \\
\text { et al. }\end{array}$ \\
\end{tabular} & $\begin{array}{l}\text { Measurement of secondary mucositis to oncohematologic treatment by means of different } \\
\text { scale. Review. }\end{array}$ & $\begin{array}{l}\text { Med Oral Patol } \\
\text { Oral Cir Bucal. }\end{array}$ & 2005 & Review \\
\hline \begin{tabular}{|l|l} 
Durie et al. & (1) \\
\end{tabular} & \begin{tabular}{|l|} 
Osteonecrosis of the jaw and bisphosphonates. \\
\end{tabular} & N Engl J Med. & 2005 & Letter \\
\hline Keim RG. & Bisphosphonates in orthodontics. & J Clin Orthod. & 2006 & Letter \\
\hline Woo et al. & Narrative [corrected] review: bisphosphonates and osteonecrosis of the jaws. & \begin{tabular}{|l|} 
Ann Intern \\
Med.
\end{tabular} & 2006 & Review \\
\hline McLeod et al. & $\begin{array}{l}\text { Bisphosphonate osteonecrosis of the jaws; an increasing problem for the dental } \\
\text { practitioner. }\end{array}$ & Br Dent $J$. & 2007 & Review \\
\hline Zahrowski JJ. I & Bisphosphonate treatment: an orthodontic concern calling for a proactive approach. & $\begin{array}{l}\text { Am J Orthod } \\
\text { Dentofacial } \\
\text { Orthop. }\end{array}$ & 2007 & Review \\
\hline Khosla et al. & $\begin{array}{l}\text { Bisphosphonate-associated osteonecrosis of the jaw: report of a task force of the } \\
\text { American Society for Bone and Mineral Research. }\end{array}$ & $\begin{array}{l}\text { J Bone Miner } \\
\text { Res. }\end{array}$ & 2007 & Letter \\
\hline Weitzman et al. & $\begin{array}{l}\text { Critical review: updated recommendations for the prevention, diagnosis, and treatment of } \\
\text { osteonecrosis of the jaw in cancer patients--May } 2006 .\end{array}$ & \begin{tabular}{|l|} 
Crit Rev Oncol \\
Hematol.
\end{tabular} & 2007 & Review \\
\hline Ruggiero et al. & Osteonecrosis of the jaws and bisphosphonate therapy. & J Dent Res. & 2007 & Review \\
\hline \begin{tabular}{|l|l} 
Landis et al. \\
\end{tabular} & Osteonecrosis of the jaws: maxillofacial recommendations for bisphosphonate prescribers. & J Intern Med. & 2007 & Letter \\
\hline Napeñas et al. & $\begin{array}{l}\text { Relationship between mucositis and changes in oral microflora during cancer } \\
\text { chemotherapy. }\end{array}$ & \begin{tabular}{|l|} 
Oral Surg \\
Oral Med Oral \\
Pathol Oral \\
Radiol Endod.
\end{tabular} & 2007 & Review \\
\hline Logan et al. & $\begin{array}{l}\text { The role of pro-inflammatory cytokines in cancer treatment-induced alimentary tract } \\
\text { mucositis: pathobiology, animal models and cytotoxic drugs. }\end{array}$ & \begin{tabular}{|l|} 
Cancer Treat \\
Rev.
\end{tabular} & 2007 & Review \\
\hline Keefe et al. & Updated clinical practice guidelines for the prevention and treatment of mucositis. & Cancer. & 2007 & Review \\
\hline Lalla et al. & Management of oral mucositis in patients who have cancer. & $\begin{array}{l}\text { Dent Clin } \\
\text { North Am. }\end{array}$ & 2008 & Review \\
\hline $\begin{array}{l}\text { Flichy- } \\
\text { Fernández } \\
\text { et al. }\end{array}$ & Bisphosphonates and dental implants: current problems. & $\begin{array}{l}\text { Med Oral Patol } \\
\text { Oral Cir Bucal. }\end{array}$ & 2009 & Review \\
\hline Fedele et al. & $\begin{array}{l}\text { Dental management of patients at risk of osteochemonecrosis of the jaws: a critical } \\
\text { review. }\end{array}$ & Oral Dis. & 2009 & Review \\
\hline Silverman et al. & Osteonecrosis of the jaw and the role of bisphosphonates: a critical review. & Am J Med. & 2009 & Review \\
\hline Bagan et al. & $\begin{array}{l}\text { Osteonecrosis of the jaws in intravenous bisphosphonate use: Proposal for a modification } \\
\text { of the clinical classification. }\end{array}$ & Oral Oncol. & 2009 & Letter \\
\hline Bagan et al. & $\begin{array}{l}\text { Osteonecrosis of the jaws in patients treated with intravenous bisphosphonates (BRONJ): } \\
\text { A concise update. }\end{array}$ & Oral Oncol. & 2009 & Review \\
\hline Hong et al. & A systematic review of dental disease in patients undergoing cancer therapy. & $\begin{array}{l}\text { Support Care } \\
\text { Cancer. }\end{array}$ & 2010 & Review \\
\hline \begin{tabular}{|l|l} 
Raber- \\
Durlacher et al.
\end{tabular} & Oral mucositis. & Oral Oncol. & 2010 & Review \\
\hline
\end{tabular}

Table 1. Articles evaluated. //RCT: Randomized Controlled Trial. 
cells of the mucosal layer. Replacement or turnover of the cells lost and desquamated in the more superficial layers of the mucosa is thus adversely affected, resulting in mucosal ulceration (1). The indirect side effects in turn are caused by non-oral actions that have a collateral impact upon the oral cavity, such as bone marrow suppression, the loss of tissue immune cells, and the loss of salivary protective elements.

\section{General side effects of chemotherapy}

Some of the most frequent side effects of chemotherapy are bone marrow suppression, resulting in leukopenia (observable in peripheral blood towards day 10 after the start of chemotherapy), thrombocytopenia (after 10-14 days) and anemia (less frequent and slower in developing). Other common effects are nausea and vomiting, hair loss (alopecia), and hand-foot syndrome (clinically characterized by painful, symmetrical erythema of the palms and soles, often preceded by paresthesias in the affected zones)(3,4). Most of the side effects gradually disappear after the end of treatment, though in some cases permanent damage may be observed at cardiac (myocardiopathy), pulmonary (fibrosis), renal (chronic renal failure) or reproductive level (sterility).

\section{Material and methods}

The present study offers a literature review of the main oral complications secondary to chemotherapy, and describes the different options for dental treatment before, during and after oncological treatment, published in the scientific literature. To this effect a PubMed-Medline ${ }^{\circledR}$ search was made using the following keywords: chemotherapy, cancer therapy, dental management, oral mucositis, neurotoxicity, intravenous bisphosphonates and jaw osteonecrosis. The search was limited to human studies published in the last 10 years in English or Spanish. The titles and summaries / abstracts of the identified articles were analyzed, with the selection of a total of 48 publications. After compiling the information on each of them, two additional articles were added, in view of their relevance: one predating the mentioned 10 -year period, and the other not indexed in the database. A total of 50 articles were thus evaluated: 17 research papers (4 clinical trials, 2 cohort studies, 2 case-control publications, 8 case series, and one cross-sectional study), 25 reviews, 6 letters to the Editor, and two clinical guides developed by expert committees (Table 1).

\section{Results}

\section{Oral side effects of chemotherapy}

The most common oral complications observed after chemotherapy are mucositis, infections, neurological and dental alterations, dysgeusia, hyposialia and xerostomia (dry mouth), bleeding tendency, and the development of osteonecrosis. The soft tissues of the lips, the oral mucosa, tongue, soft palate and the pharyngeal mucosa are the most affected areas.

\section{Mucositis}

Mucositis is an inflammatory reaction of the mucosal membranes secondary to antineoplastic treatments such as radiotherapy (in $80 \%$ of the cases) and chemotherapy as treatment for solid tumors or lymphomas (in approximately $40-50 \%$, particularly with the cytostatic agent 5 -fluorouracil) or as conditioning treatment for bone marrow transplantation (in over $75 \%$ of the patients)(5-7). Mucositis is regarded as a manifestation of leukopenia. The mechanism by which mucositis develops is not clear, though it is generally attributed to the fact that the oral mucosal cells have a relatively high mitotic rate, thereby establishing them as targets of the action of cytostatic agents $(5,8,9)$. Diseases such as diabetes and cardiovascular disorders have been described as possible risk factors, though no direct relationship has been found (10). According to Logan et al. (2007), there are 5 stages in the clinical mucosal changes that give rise to mucositis: initiation; over-regulation and the production of mediators; signaling and amplification; ulceration; and healing (Fig. 1)(9). This hypothesis underscores the role of transcription factors and proinflammatory cytokines in the development of mucositis (9).

Mucositis usually appears 4-7 days after the start of highdose chemotherapy, and is of a self-limiting nature (provided overinfection does not occur). It in turn disappears 2-4 weeks after the conclusion of cytotoxic chemotherapy (11). The drugs most often associated with the development of mucositis are doxorubicin, bleomycin, fluorouracil and methotrexate (12). Clinically, the condition manifests as erythema, edema or ulceration, with severe pain, bleeding and potential side effects such as xerostomia, the risk of both local (overinfection due to Candida) and systemic infection, malnutrition, fatigue, dental caries and gastrointestinal disorders over time (5). Because of these complications, in some cases the patient may require parenteral nutrition and even potent analgesics, administered in the hospital setting $(8,9,12)$. Different methods have been developed for measuring and quantifying the changes occurring in the oral mucosa, including general scales, multiple-variable scales and treatment specific scales (8). The currently most widely used scale is that of the World Health Organization (WHO), based on the identification of erythema at exploration and the degree of patient discomfort or pain (5).

Regarding the prevention and treatment of mucositis, studies have been made with different agents (sucralfate, chlorhexidine, povidone iodine, doxepin, benzidamine, cryotherapy, low-energy laser, etc.), though none have been shown to prevent the disorder $(6,13)$. Donelly et al. (2003) carried out a systematic review in which $42 \%$ of the published studies (13 articles) reported that the ad- 


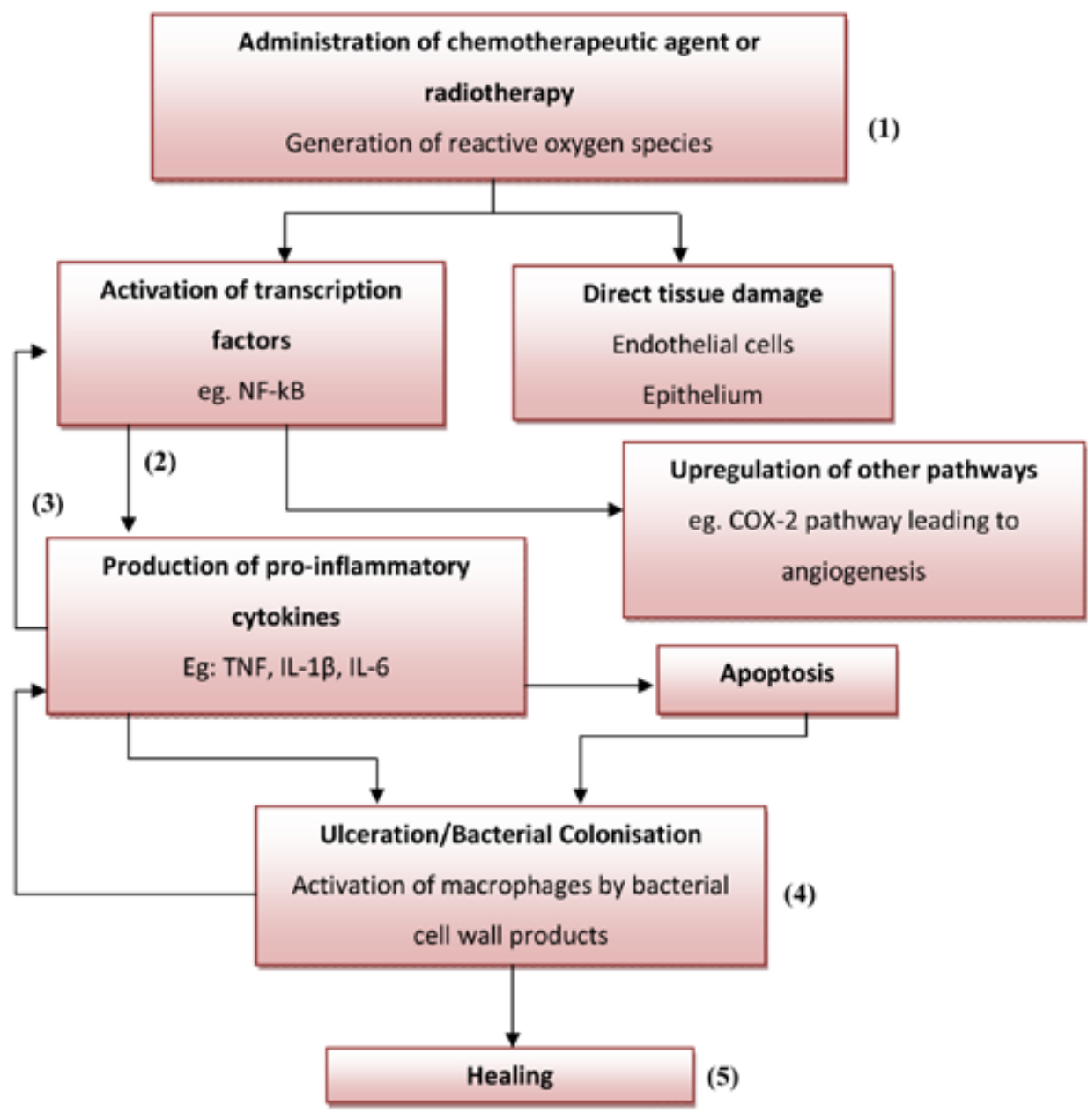

NORMAL CLINICAL APPEARANCE

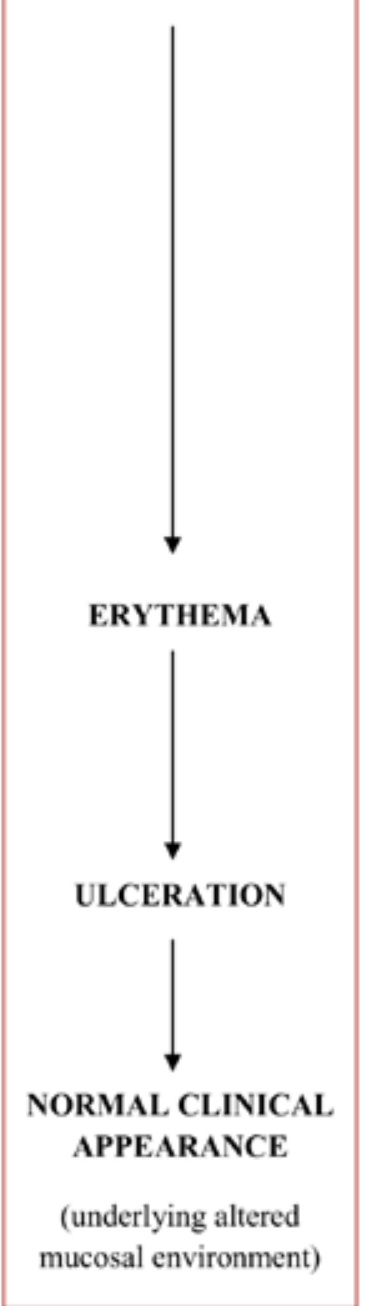

Fig.1. Diagram illustrating mucosal and clinical changes that occur leading to mucositis according to the current hypothesis. The five overlapping stages are demonstrated (1) initiation; (2) upregulation and message generation; (3) signalling and amplification; (4) ulceration; (5) healing. Figure belongs to article made by Logan et al. (9).

ministration of antimicrobial agents offers some benefit in relation to the symptoms of mucositis (14). However, Clarkson et al. (2004), in a Cochrane review of 27 publications, found that among 8 prophylactic agents used to obtain relief from mucositis, crushed ice yielded the best results (15). Posteriorly, Keefe et al. (2007) published an update on the clinical guides for the prevention and treatment of oral and gastrointestinal mucositis (16). The currently most widely used treatment is the use of $2 \%$ lidocaine rinses in combination with $0.12-0.2 \%$ chlorhexidine during 30 seconds, every three or four hours. Colella et al. (2010) have suggested that the frequent application of a spray consisting of synthetic collagen precursor amino acids in combination with sodium hyaluronate can offer rapid and effective pain relief, and contributes to mucosal healing - though further randomized and controlled studies are needed to more firmly establish its usefulness (17).

\section{Oral infections}

Dental treatment prior to the start of cytoreductive therapy substantially reduces the risk of severe infections $(1,5)$. The main infectious processes are the following: 1. Bacterial infections: These are usually caused by gramnegative organisms. Signs of inflammation may be masked as a result of the underlying bone marrow suppression; consequently, oral hygiene protocols that reduce microbial colonization of the dentition and periodontium are important during the period of bone marrow suppression. During oncological treatment, and particularly in patients with advanced-stage malignancies, it is common to observe poorer oral hygiene, and thus an increased presence of dental plaque (18). In the study published by López-Galindo et al. (2006), increased dental plaque was observed, along with more caried and mis- 
sing teeth, among oncological patients prior to treatment - though the modified periodontal index was similar in both the oncological patients and controls (1). Patients with previous dental and periodontal diseases eliminated before the start of oncological therapy and subjected to intensive dental care during therapy show a significant reduction in the frequency of oral complications associated to chemotherapy $(1,19)$. Teeth with an unfavorable prognosis should be removed at least 10 days before the start of chemotherapy (20).

2. Fungal infections: Bone marrow suppression, oral mucosal lesions and salivary alterations contribute to the development of Candida albicans infection (18). The most common presentations are pseudomembranous candidiasis, followed by erythematous candidiasis. The treatment of these conditions involves the use of topical and/or systemic antifungal agents (Table 2) complemented with an antiseptic (chlorhexidine). The latter should be used at least 30 minutes before or after nystatin, since the combination of both may prove ineffective. In the case of more severe infections, the recommendation is a systemic antifungal such as fluconazole or ketoconazole. The efficacy of such treatment is limited, and resistances may appear. In such cases intravenous amphotericin B or itraconazole via the oral route at a dose of 200-400 $\mathrm{mg} /$ day tend to be the drugs of choice.

3. Viral infections: In most cases, infections due to her- pes simplex virus (HSV), varicella-zoster virus (VZV) and Epstein-Barr virus (EBV) are the result of the reactivation of a latent virus, while infections due to cytomegalovirus (CMV) can result from the reactivation of a latent virus or from a recently acquired virus (20).

Infection due to HSV: The severity of the lesions increases drastically with the degree of immune suppression. The HSV lesions are more diffuse but less painful than those associated with radiotherapy. Moreover, recurrent intraoral HSV infection may present ulcerations of mucosal areas not adhered to periosteum (i.e., soft palate and tongue)(20). The incidence of oral lesions due to recurrent HSV infections in bone marrow-suppressed cancer patients has decreased considerably following the introduction of prophylactic aciclovir at a dose of $800 \mathrm{mg} /$ day, beginning on day four after the start of chemotherapy. In patients without antiviral prophylaxis, the oral lesions generally appear simultaneously with chemotherapy or chemo-radiotherapy during the period of most intense immune suppression. The treatment of HSV infection consists of the administration of 400-800 $\mathrm{mg}$ of aciclovir via the oral route 5 times a day or of 5-10 $\mathrm{mg} / \mathrm{kg}$ via the intravenous route every 8-12 hours, for as long as the lesions persist.

Infection due to $V Z V$ : Immune compromised patients may present involvement of several dermatomes, or alternatively the lesions may show a more generalized

\begin{tabular}{|c|c|c|c|c|c|c|c|}
\hline \multirow{7}{*}{$\begin{array}{c}\text { ORAL } \\
\text { CANDIDIASIS }\end{array}$} & $\begin{array}{l}\text { TYPE OF } \\
\text { ADMINIS- } \\
\text { TRATION }\end{array}$ & DRUG & NAME & DOSE & \multicolumn{2}{|c|}{ DOSAGE } & DURATION \\
\hline & \multirow[t]{2}{*}{ Topical } & Nystatin & Mycostatin $^{\circledR}$ & $\begin{array}{l}100.000 \\
\text { I.U./cc } \\
\text { rinses }\end{array}$ & \multicolumn{2}{|c|}{ 4-6 times/day } & 30 days \\
\hline & & Miconazole & $\begin{array}{l}\text { Daktarin }^{\circledR} \text { gel } \\
\text { Fungisdin }^{\circledR} \text { gel }\end{array}$ & $\begin{array}{c}100 \mathrm{mg} \\
\text { gel }\end{array}$ & \multicolumn{2}{|c|}{4 times/day } & 30 days \\
\hline & & Fluconazole & Diflucan $^{\circledR}$ & $\begin{array}{c}150 \mathrm{mg} \\
\text { orally }\end{array}$ & \multicolumn{2}{|c|}{1 time/day } & 3 weeks \\
\hline & Systemic & Ketoconazole & $\begin{array}{l}\text { Fungarest }^{\circledR} \\
\text { Ketoisdin }^{\circledR} \\
\text { Panfungol }\end{array}$ & $\begin{array}{l}200- \\
400 \mathrm{mg} \\
\text { orally }\end{array}$ & \multicolumn{2}{|c|}{1 time/day } & 3 weeks \\
\hline & & Itraconazole & $\begin{array}{l}\text { Canadiol }^{\circledR} \\
\text { Hongoseril }^{\circledR} \\
\text { Spranox }^{\circledR}\end{array}$ & $\begin{array}{l}200- \\
400 \mathrm{mg} \\
\text { orally }\end{array}$ & \multicolumn{2}{|c|}{1 time/day } & 30 days \\
\hline & Intravenous & AmphotericinB & Ambisome $^{\circledR}$ & $\begin{array}{l}0,4-0,6 \\
\mathrm{mg} / \mathrm{kg}\end{array}$ & \multicolumn{2}{|c|}{1 time/day } & 30 days \\
\hline \multirow[b]{2}{*}{ VZV } & \multicolumn{2}{|c|}{$\begin{array}{l}\text { SEVERE IMMUNE } \\
\text { COMPROMISED }\end{array}$} & \multicolumn{3}{|c|}{$\begin{array}{l}\text { LESS SEVERE IMMUNE } \\
\text { COMPROMISED }\end{array}$} & \multicolumn{2}{|c|}{ RESISTANCES } \\
\hline & \multicolumn{2}{|c|}{$\begin{array}{l}\text { - Aciclovir intravenously 5-10 } \\
\text { mg/Kg } 3 \text { times/day during } 5 \text { days. }\end{array}$} & \multicolumn{3}{|c|}{$\begin{array}{l}\text { - Aciclovir } 800 \mathrm{mg} \text { orally/ } 5 \text { times } \\
\text { per day/ } 5-7 \text { days. } \\
\text { - Famciclovir } 500 \mathrm{mg} \text { orally/ } 3 \text { times } \\
\text { per day/ } 7 \text { days. } \\
\text { - Valaciclovir } 1000 \mathrm{mg} \text { orally/ } 3 \\
\text { times per day/ } 7 \text { days. }\end{array}$} & \multicolumn{2}{|c|}{$\begin{array}{l}\text { - Foscarnet intravenously } \\
40 \mathrm{mg} / \mathrm{kg} / 3 \text { times per day. }\end{array}$} \\
\hline
\end{tabular}

Table 2. Treatment of oral candidiasis and infection due to VZV in the chemotherapy patient. 
distribution, generally manifesting several weeks after the interruption of chemotherapy - in contrast to the situation with HSV. A number of antiviral agents are used as treatment, depending on the degree of immune suppression of the patient and the resistances to these drugs (Table 2).

Infection due to $C M V$ and $E B V$ : Lesions produced by CMV are characterized by the presence of multiple mild or moderate ulcerations with irregular margins. The initial lesions appear during the first periods of bone marrow regeneration and are characterized by nonspecific pseudomembranous ulcers covered by a fibrin exudate with a granulomatous base. At present, ganciclovir is the treatment of choice for acute CMV infection. The risk of EBV infection usually manifests months after the interruption of myeloablative therapy used for transplant conditioning.

Neurotoxicity

A number of chemotherapeutic agents such as vincristine and vinblastine are able to cause direct neurotoxicity. Patients may experience deep and palpitating mandibular pain that tends to subside one week after concluding chemotherapy. A correct anamnesis is required, together with oral exploration and an X-ray study in order to distinguish such pain from pain of pulp origin. In some cases, dental hypersensitivity may appear weeks or months after the end of chemotherapy; in these cases, the topical application of fluoride or the use of a desensitizing toothpaste may help lessen the symptoms.

Dysgeusia

During chemotherapy, patients may experience an unpleasant metallic taste due to diffusion of the chemotherapeutic agent into the oral cavity. Dysgeusia as such initially manifests a few weeks after starting cytotoxic treatment, and is generally reversible within a few weeks. The CMF (cyclophosphamide, methotrexate and 5-fluorouracil) and CEF protocol agents (cyclophosphamide, epirubicin and 5-fluorouracil), and their derivatives, can be detected in saliva for days after the infusion (18). Dysgeusia is an important symptoms in these patients, since apart from the direct neurotoxic effect upon the gustatory cells, it is reinforced by other factors such as xerostomia, infections, and the psychological conditions of the patient (21).

\section{Hyposialia and xerostomia}

Hyposialia, attributable to the effect of chemotherapy upon the cells of the salivary glands, is transient and reversible. It appears particularly with the use of adriamycin, and can cause oral functional problems, especially in relation to speech and mastication. These patients show alterations in the salivary components, with an increase in the levels of peroxidase and amylase, a reduction in total secreted immunoglobulins $A$ and $G$, and the presence of the chemotherapeutic drug itself. All these factors favor the development of mucositis (21).
As a result, patients should drink abundant water and use sugar-free sweets or chewing gum to increase salivation. In more moderate cases, sialogogues such as pilocarpine, bromhexine or bethanechol can be used.

Alterations in dental growth and development

Unlike radiotherapy, which only affects the cells within the irradiated zone, chemotherapy has a systemic effect. As a result, the developing odontogenic cells are susceptible to chemotherapy, even when far removed from the tumor site. Minicucci et al. (2003) detected delays in dental development, hypoplasia and microdontia in children receiving chemotherapy (22).

Bleeding tendency

Bleeding is due to alterations resulting from thrombocytopenia (in turn a consequence of bone marrow aplasia). Clinically, patients my present petechiae, ecchymosis, hematomas or diffuse bleeding. Rinses with $0.12 \%$ chlorhexidine avoid overinfection and can help eliminate the traces of blood, though caution is required in order not to alter the clots, since this could lead to further bleeding. In the presence of platelet counts of under $50,000 / \mathrm{mm} 3$, tooth extractions or dental surgery should not be performed, while counts of under 20,000 platelets $/ \mathrm{mm} 3$ are associated with spontaneous bleeding - particularly in patients with previous gingivitis. The treatments of choice in the event of bleeding comprise the use of vasoconstrictors such as topical epinephrine, mucoadherent tissue protectors such as the cyanoacrylates (which seal the bleeding sites and protect the formed clots), and procoagulating agents such as topical thrombin or hemostatic collagen, which organize and stabilize the blood clots. The risk of infection or bleeding in these patients persists for the duration of the effect of the cytotoxic drugs administered in each chemotherapy session. Osteonecrosis

Osteonecrosis of the jaw (ONJ) is observed in patients treated with bisphosphonates (BPs). These drugs inhibit bone resorption and are administered via the intravenous route as treatment in application to bone metastases in cancer patients, in malignant hypercalcemia (tumorinduced hypercalcemia), or in patients with multiple myeloma - affording improved survival and quality of life (23). Although much less commonly, ONJ has also been observed in patients receiving treatment with oral bisphosphonates (used for the prevention and treatment of osteoporosis and in certain bone conditions such as Paget's disease). The intravenous BPs most associated with ONJ are zoledronic acid (Zometa $\left.{ }^{\circledR}\right)$ and pamidronate (Aredia ${ }^{\circledR}$ ).

The precise incidence of ONJ in cancer patients is not known, since the figures differ according to the literature source $(0.8 \%-12 \%)(24-26)$. Recent studies such as those published by Bagán et al. (2009) suggest an incidence of 1-3\% among oncological patients receiving treatment with intravenous bisphosphonates (27). Although these 


\begin{tabular}{|l|l|l|}
\hline \multicolumn{1}{|c|}{$\begin{array}{c}\text { STAGING } \\
\text { CLASSIFICATION }\end{array}$} & \multicolumn{1}{|c|}{ CLINICAL MANIFESTATIONS } & \multicolumn{1}{c|}{ TREATMENT } \\
\hline STAGE 1 & $\begin{array}{l}\text { Exposed bone necrosis or small oral } \\
\text { ulceration without exposed bone necrosis, } \\
\text { but without symptoms. }\end{array}$ & $\begin{array}{l}\text { Rinses with } 0.12 \% \\
\text { chlorhexidine and checkup. }\end{array}$ \\
\hline STAGE 2A & $\begin{array}{l}\text { Exposed bone necrosis or a small oral fistula } \\
\text { without exposed bone necrosis, but with } \\
\text { Symptoms controlled with medical } \\
\text { treatment. }\end{array}$ & $\begin{array}{l}\text { Rinses with } 0.12 \% \\
\text { chlorhexidine, antibiotic, } \\
\text { analgesics and checkup. }\end{array}$ \\
\hline STAGE 2B & $\begin{array}{l}\text { Exposed bone necrosis or a small oral } \\
\text { fistula without exposed bone necrosis, but } \\
\text { with symptoms not controlled with medical } \\
\text { treatment. }\end{array}$ & $\begin{array}{l}\text { Rinses with 0.12\% } \\
\text { chlorhexidine, antibiotic, } \\
\text { analgesics and surgery with } \\
\text { removal of the zone of bone } \\
\text { necrosis. }\end{array}$ \\
\hline STAGE 3 & $\begin{array}{l}\text { Jaw fractures, skin fistula, osteolysis } \\
\text { extending to the inferior border. }\end{array}$ & $\begin{array}{l}\text { Rinses with } 0.12 \% \\
\text { chlorhexidine, antibiotic, } \\
\text { analgesics and extensive } \\
\text { surgery with resection of } \\
\text { bone. }\end{array}$ \\
\hline
\end{tabular}

Table 3. Staging classification and treatment of osteonecrosis of the jaws by bisphosphonates. In the case of normal flora for 15 days, it is recommended the use of amoxicillin/clavunate, doxycicline or azytromycin as antibiotic of choice.

estimations point to a low percentage of $\mathrm{ONJ}$, an increasing number of cases are being detected, and the figures can be expected to continue to increase in the future $(23,27)$. ONJ tends to appear after invasive dental manipulation, particularly after tooth extraction - the latter being the most important triggering factor in the development of ONJ $(23,24,26-30)$. Habits such as smoking and alcohol consumption have been more closely related to the development of osteoradionecrosis (ORN) than to ONJ. In the study published by Bagán et al. (2009), $22.6 \%$ of the patients who developed ONJ were smokers, versus $60 \%$ of the patients with ORN (29).

In 2008, a national expert committee with the representation of maxillofacial surgeons, stomatologists and odontologists, established a series of recommendations on how to conduct oral revisions, defining those dental treatments that should be carried out before and during treatment with intravenous bisphosphonates (23). The diagnostic criteria for ONJ established by these experts were: patients receiving or having received treatment with BPs; the presence of one or more ulcerated mucosal lesion of the alveolar processes, with or without the exposure of maxillary or mandibular bone; exposed bone presenting a necrotic appearance; lesions presenting spontaneously or after dentoalveolar surgery (particularly extractions); and the absence of healing over a period of at least 6 weeks.

Clinically, ONJ is typically characterized by pain (progressive and sustained, and sometimes requiring important analgesic doses to secure control - the patient being asymptomatic in the early stages)(30-33). In order to establish and plan the treatment of ONJ, Bagán et al. (2009) proposed a modification of the staging classifi- cation used up to that time (30). Table 3 describes the different clinical stages and corresponding treatments. Although the clinical manifestations are usually sufficient to establish the diagnosis, in those cases where doubts exist regarding the differential diagnosis between ONJ and bone metastasis, a biopsy is advisable. Other complementary diagnostic tests are culture of the exposed zone and definition of the corresponding antibiogram, together with a panoramic X-ray and computed tomography study (27). Another technique subject to discussion is the evaluation of the serum concentrations of CTX (collagen fragments that are freed during bone remodeling and turnover), since BPs reduce these concentrations. It is therefore believed that CTX determination may be a reliable risk marker, though a number of studies have found no statistically significant relationship between the serum levels of CTX and the number of areas of exposed necrotic bone or magnitude of ONJ $(27,34)$.

Since the treatment of ONJ is often unsatisfactory, management should aim to afford pain relief, control soft tissue and bone infection, and avoid or reduce the progression of bone necrosis $(28,35)$.

2. Dental treatment before, during and after chemotherapy

All oncological patients should visit the dentist before receiving radiotherapy, chemotherapy or both, since the severity of the oral complications can be significantly reduced if a prior intensive strategy is applied to secure stabilized oral hygiene.

Treatment before chemotherapy

Before chemotherapy, the dentist should consult the oncologist to determine the current condition of the patient 


\begin{tabular}{|c|c|c|}
\hline $\begin{array}{l}\text { TREATMENT BEFORE } \\
\text { CHEMOTHERAPY }\end{array}$ & $\begin{array}{l}\text { TREATMENT DURING } \\
\text { CHEMOTHERAPY }\end{array}$ & $\begin{array}{l}\text { TREATMENT AFTER } \\
\text { CHEMOTHERAPY }\end{array}$ \\
\hline $\begin{array}{l}\text { - The dentist should consult the } \\
\text { oncologist to determine the current } \\
\text { condition of the patient and the type } \\
\text { of treatment planned. }\end{array}$ & $\begin{array}{l}\text { The oncologist should be consulted in } \\
\text { order to know the degree of immune } \\
\text { suppression of the patient. }\end{array}$ & $\begin{array}{l}\text { - The dentist should consult the } \\
\text { oncologist to determine immune } \\
\text { competence. }\end{array}$ \\
\hline $\begin{array}{l}\text { - Exhaustive examination of the oral } \\
\text { cavity: discard periapical lesions } \\
\text { and/or bone alterations, and the } \\
\text { evaluation of periodontal health. } \\
\text { - Denture fitting should be checked, } \\
\text { with readjustment or removal } \\
\text { of those prostheses that prove } \\
\text { traumatic. } \\
\text { - Radiological study: intraoral } \\
\text { (periapical and bitewing) and } \\
\text { panoramic. }\end{array}$ & $\begin{array}{l}\text { - Treatment of the complications } \\
\text { of chemotherapy (mucositis, } \\
\text { xerostomia...). }\end{array}$ & $\begin{array}{l}\text { - Insist on the need for routine } \\
\text { systematic oral hygiene. } \\
\text { - Use of chlorhexidine rinses and } \\
\text { fluorization. }\end{array}$ \\
\hline $\begin{array}{l}\text { - Generalprophylacticmeasures:tartar } \\
\text { removal, dental fluorization and } \\
\text { rinses with } 0.12 \% \text { chlorhexidine. }\end{array}$ & $\begin{array}{l}\text { - Continued patient reminder of the } \\
\text { need to maintain strict dental hygiene } \\
\text { is indicated, with the added use of } \\
\text { chlorhexidine rinses and fluorization. }\end{array}$ & \\
\hline $\begin{array}{l}\text { - The patient should be informed of } \\
\text { the complications of treatment. }\end{array}$ & $\begin{array}{l}\text { - } \text { Analgesics: paracetamol/metamizol. } \\
\text { - NO NSAID. } \\
\text { - Antibiotics: dose adjustment is } \\
\text { required according to the observed } \\
\text { creatinine clearance values in patients } \\
\text { with kidney problems. }\end{array}$ & \\
\hline $\begin{array}{l}\text { - } \begin{array}{l}\text { Teeth that are non-viable or present a } \\
\text { poor prognosis should be removed: }\end{array} \\
\text { Minor surgery: al least two weeks } \\
\text { before chemotherapy. } \\
\text { Major surgery: 4-6 weeks before } \\
\text { chemotherapy. }\end{array}$ & $\begin{array}{l}\text { No elective dental treatment should be } \\
\text { carried out. } \\
\text { ONLY emergency dental care. }\end{array}$ & - Elective dental treatment. \\
\hline
\end{tabular}

Table 4. Dental treatment before, during and after chemotherapy.

and the type of treatment planned (Table 4). In addition, an exhaustive examination of the oral cavity is required, together with a radiological study (intraoral - periapical and bitewing - and panoramic) in order to discard periapical lesions and/or bone alterations, and the evaluation of periodontal health.

Denture fitting is to be checked, with readjustment or removal of those prostheses that prove traumatic, and all infectious foci are to be eliminated (caries, fillings in poor condition).

Dental fluorization is indicated, as well as rinses with $0.12 \%$ chlorhexidine and general prophylactic measures. In children, sealing of cracks and fissures in recently erupted molars and premolars is advised. Adequate oral health conditions should be sought before chemotherapy is applied, since the negative effects of the latter are more limited when the oral cavity is healthy than when there are pre-existing dental or periodontal problems $(1,2)$.

Teeth that are non-viable or present a poor prognosis (pericoronitis, extensive caries, advanced periodontal disease and periapical disorders) should be removed at least two weeks before, while major surgical procedures should be carried out 4-6 weeks before chemotherapy. The patient should be informed of the complications of treatment (e.g., mucositis).

If the patient is to receive treatment with intravenous $B P s$

In patients programmed to receive intravenous BPs, the above described measures are likewise applicable, and moreover the dentist should inform the oncologist of 
the planned treatment (particularly surgical treatment), in case it is possible to postpone therapy until wound healing has been achieved (4-6 weeks are recommended)(23,36). Two independent studies have shown that opportune dental detection and preventive treatment significantly reduce the risk of ONJ versus the controls $(6.7 \%$ versus $26.3 \%$, and $3.2 \%$ versus $1.3 \%$, respectively)(37,38). If surgery proves necessary, prior informed consent is to be obtained, and the operation should be minimally traumatic in order to secure good and rapid

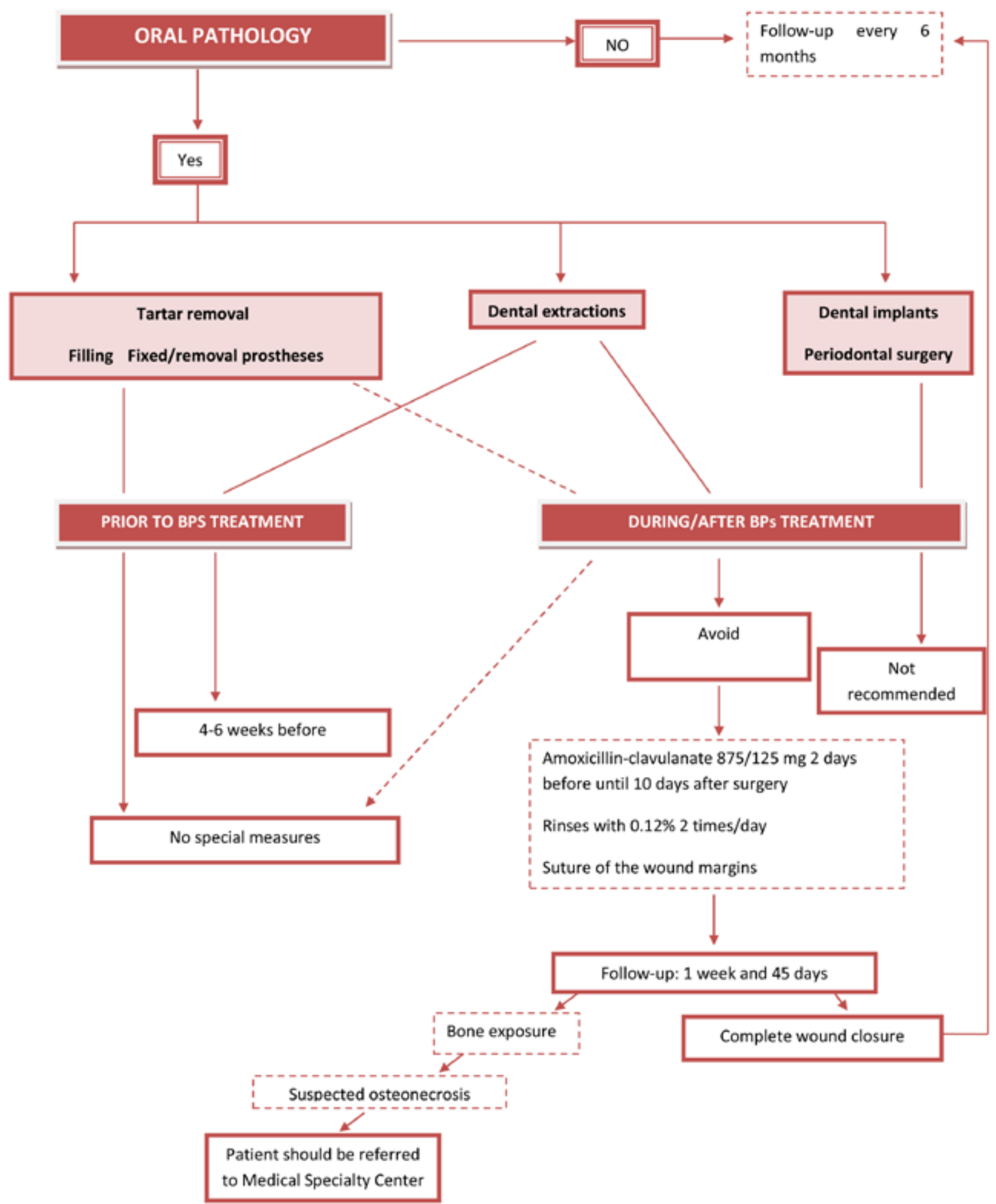

Fig. 2. Algorithm: dental treatment before, during and after chemotherapy in patients treated with intravenous bisphosphonates. BPs: bisphosphonates; ONJ: osteonecrosis of the jaw; CLX: chlorhexidine. 
healing.

\section{Treatment during chemotherapy}

The oncologist is to be consulted in order to know the degree of immune suppression of the patient. Continued patient reminder of the need to maintain strict dental hygiene is indicated, with the added use of chlorhexidine rinses and fluorization.

During this period, the previously mentioned complications of chemotherapy are to be treated (mucositis, xerostomia, etc.). No elective dental treatment should be carried out (Table 4), and intervention is to be limited to infectious processes and pain (i.e., emergency dental care).

In these cases, great caution is required with the administration of drugs, since all antineoplastic agents cause bone marrow suppression to one degree or other, as well as variable liver toxicity, nephrotoxicity, ototoxicity and gastrointestinal disorders. It is preferable to use paracetamol or metamizol, due to the interactions that occur between nonsteroidal antiinflammatory drugs and immunosuppressors (with corticosteroids: risk of gastric ulcer; with cyclosporine: nephrotoxicity; with methotrexate: risk of bleeding). For the administration of antibiotics, and in the case of kidney problems, dose adjustment is required according to the observed creatinine clearance values.

If the patient is receiving treatment with intravenous $B P S$

There are no contraindications to conservative dental treatment in patients receiving intravenous BPs (36-38). In this context, tartar removal can be carried out, with a view to eliminating this source of mechanical and biological irritation. Removable dentures are not contraindicated, though the dentist must be particularly carefully to avoid the development of friction ulcers, and any such lesions must be treated as soon as possible $(24,31,32,39)$. If such ulcers appear, the dentures must be removed, followed by patient control after 7-10 days. During this period, it is advisable for the dentist to examine the patient every 6 months (23).

Scaling and root planing are only advised where strictly necessary in order to avoid irritation of the alveolar bone and overlying mucosa. Periodontal treatment with flap raising is not indicated, since it requires bone exposure, with the consequent risk of ONJ (Fig. 2).

Whenever possible, tooth extractions are to be avoided, with conservative management of those lesions that exceed the amelodentinal limit $(24,32)$. If extraction proves necessary, the recommendations of the Spanish expert committee should be followed (23): before any surgical intervention, the patient is to be carefully informed of the risks of ONJ, with signing of the corresponding consent document. Different authors recommend the suspension of BP therapy, though there is no evidence that such suspension prevents the development of ONJ, since the half-life of bisphosphonates is extremely long (39). Tooth extraction should be minimally traumatic, with curettage of the socket, cleansing of the surgical bed and suturing of the wound margins. Antibiotic prophylaxis is to be provided before and after extraction.

Regarding dental implant placement in these patients, the available data are very limited, though all the studies found in the literature speak against such treatment (24,32,39-41).

Orthodontic treatment in these patients is not recommended, due to the seriousness of their background illness, and due to the important osteoclastic inhibition induced by bisphosphonate therapy, which limits or impedes the bone reabsorption required for dental displacement (41).

\section{Treatment after chemotherapy}

Provided immune competence has been restored, and after consulting the oncologist, elective treatment may be provided, designed to restore or achieve good esthetic results and adequate function. The presence of infectious foci moreover should be minimized. The usual protocols for the management of odontogenic infections are applicable in such cases (Table 4). It is also important to insist on the need for routine systematic oral hygiene in order to reduce the incidence and severity of the oral sequelae of antineoplastic therapy.

If the patient has received treatment with intravenous $B P S$

In those patients who have received treatment with intravenous BPs, the considerations for dental care are the same as in patients receiving treatment with intravenous BPs, since the half-life of these drugs ranges from 1-10 years. When placing dental implants, it must be taken into account that a series of metabolic changes take place around the implant, leading to the formation of bone intimately bound to the implant surface (osseointegration)(40). If the surrounding bone contains medium to high levels of BPs, such bone turnover and remodeling is hindered or prevented, with a high probability of necrosis developing in the surrounding bone. The situation is different when patients who start to receive treatment with BPs already have dental implants (Fig. 2).

\section{References}

1. López-Galindo MP, Bagán JV, Jiménez-Soriano Y, Alpiste F, Camps C. Clinical evaluation of dental and periodontal status in a group of oncological patients before chemotherapy. Med Oral Patol Oral Cir Bucal. 2006;11:E17-21.

2. Caribé-Gomes F, Chimenos-Küstner E, López-López J, FinestresZubeldia F, Guix-Melcior B. Dental management of the complications of radio and chemotherapy in oral cancer. Med Oral. 2003;8:178-87.

3. Grunberg SM, Deuson RR, Mavros P, Geling O, Hansen M, Cruciani $\mathrm{G}$, et al. Incidence of chemotherapy-induced nausea and emesis after modern antiemetics. Cancer. 2004;100:2261-8.

4. Hueso L, Sanmartín O, Nagore E, Botella-Estrada R, Requena C, Llombart B, et al. Chemotherapy-induced acral erythema: a clinical and histopathologic study of 44 cases. Actas Dermosifiliogr. 2008;99:281-90. 
5. Stone R, Fliedner MC, Smiet AC. Management of oral mucositis in patients with cancer. Eur J Oncol Nurs. 2005;9:S24-32.

6. Hejna M, Köstler WJ, Raderer M, Steger GG, Brodowicz T, Scheithauer W, et al. Decrease of duration and symptoms in chemotherapyinduced oral mucositis by topical GM-CSF: results of a prospective randomised trial. Eur J Cancer. 2001;37:1994-2002.

7. Lalla RV, Sonis ST, Peterson DE. Management of oral mucositis in patients who have cancer. Dent Clin North Am. 2008;52:61-77, viii.

8. López-Castaño F, Oñate-Sánchez RE, Roldán-Chicano R, Cabrerizo-Merino MC. Measurement of secondary mucositis to oncohematologic treatment by means of different scale. Review. Med Oral Patol Oral Cir Bucal. 2005; 10: 412-21.

9. Logan RM, Stringer AM, Bowen JM, Yeoh AS, Gibson RJ, Sonis ST, et al. The role of pro-inflammatory cytokines in cancer treatmentinduced alimentary tract mucositis: pathobiology, animal models and cytotoxic drugs. Cancer Treat Rev. 2007;33:448-60.

10. Barasch A, Peterson DE. Risk factors for ulcerative oral mucositis in cancer patients: unanswered questions. Oral Oncol. 2003;39:91100 .

11. Raber-Durlacher JE, Elad S, Barasch A. Oral mucositis. Oral Oncol. 2010;46:452-6.

12. Napeñas JJ, Brennan MT, Bahrani-Mougeot FK, Fox PC, Lockhart PB. Relationship between mucositis and changes in oral microflora during cancer chemotherapy. Oral Surg Oral Med Oral Pathol Oral Radiol Endod. 2007;103:48-59.

13. Antunes HS, Ferreira EM, Matos VD, Pinheiro CT, Ferreira CG. The Impact of low power laser in the treatment of conditioning-induced oral mucositis: A report of 11 clinical cases and their review. Med Oral Patol Oral Cir Bucal. 2008; 13: E189 -92.

14. Donnelly JP, Bellm LA, Epstein JB, Sonis ST, Symonds RP. Antimicrobial therapy to prevent or treat oral mucositis. Lancet Infect Dis. 2003;3:405-12.

15. Clarkson JE, Worthington HV, Eden OB. Interventions for treating oral candidiasis for patients with cancer receiving treatment. Cochrane Database Syst Rev. 2004;(1):CD001972.

16. Keefe DM, Schubert MM, Elting LS, Sonis ST, Epstein JB, RaberDurlacher JE, et al. Updated clinical practice guidelines for the prevention and treatment of mucositis. Cancer. 2007;109: 820-31.

17. Colella G, Cannavale R, Vicidomini A, Rinaldi G, Compilato D, Campisi G. Efficacy of a spray compound containing a pool of collagen precursor synthetic aminoacids (1-proline, 1-leucine, 1-lysine and glycine) combined with sodium hyaluronate to manage chemo/ radiotherapy-induced oral mucositis: preliminary data of an open trial. Int J Immunopathol Pharmacol. 2010;23:143-51.

18. Jensen SB, Mouridsen HT, Bergmann OJ, Reibel J, Brünner N, Nauntofte B. Oral mucosal lesions, microbial changes, and taste disturbances induced by adjuvant chemotherapy in breast cancer patients. Oral Surg Oral Med Oral Pathol Oral Radiol Endod. 2008;106:21726.

19. Hong CH, Napeñas JJ, Hodgson BD, Stokman MA, Mathers-Stauffer V, Elting LS, et al. A systematic review of dental disease in patients undergoing cancer therapy. Support Care Cancer. 2010 May 7. 20. Raber-Durlacher JE, Epstein JB, Raber J, van Dissel JT, van Winkelhoff AJ, Guiot HF, et al. Periodontal infection in cancer patients treated with high-dose chemotherapy. Support Care Cancer. 2002;10:466-73.

21. Epstein JB, Tsang AH, Warkentin D, Ship JA. The role of salivary function in modulating chemotherapy-induced oropharyngeal mucositis: a review of the literature. Oral Surg Oral Med Oral Pathol Oral Radiol Endod. 2002;94:39-44.

22. Minicucci EM, Lopes LF, Crocci AJ. Dental abnormalities in children after chemotherapy treatment for acute lymphoid leukemia. Leuk Res. 2003;27:45-50.

23. Bagán JV, Diz-Dios P, Gallego L, Infante-Cossío P, Jiménez Y, Junquera LM, y cols. Recomendaciones para la prevención de la osteonecrosis de los maxilares (ONM) en pacientes con cáncer tratados con bisfosfonatos intravenosos. Med Oral Patol Oral Cir Bucal. 2008;13:161-7.

24. Bamias A, Kastritis E, Bamia C, Moulopoulos LA, Melakopoulos
I, Bozas G, et al. Osteonecrosis of the jaw in cancer after treatment with bisphosphonates: incidence and risk factors. J Clin Oncol. 2005;23:8580-7.

25. McLeod NM, Davies BJ, Brennan PA. Bisphosphonate osteonecrosis of the jaws; an increasing problem for the dental practitioner. $\mathrm{Br}$ Dent J. 2007;203:641-4.

26. Boonyapakorn T, Schirmer I, Reichart PA, Sturm I, Massenkeil G. Bisphosphonate-induced osteonecrosis of the jaws: prospective study of 80 patients with multiple myeloma and other malignancies. Oral Oncol. 2008;44:857-69.

27. Bagan J, Scully C, Sabater V, Jimenez Y. Osteonecrosis of the jaws in patients treated with intravenous bisphosphonates (BRONJ): A concise update. Oral Oncol. 2009;45:551-4

28. Jimenez-Soriano Y, Bagan JV. Bisphosphonates, as a new cause of drug-induced jaw osteonecrosis: An update. Med Oral Patol Oral Cir Bucal. 2005;10:E88-91.

29. Bagan JV, Jiménez Y, Hernández S, Murillo J, Díaz JM, Poveda $\mathrm{R}$, et al. Osteonecrosis of the jaws by intravenous bisphosphonates and osteorradionecrosis: a comparative study. Med Oral. 2009; 14 : e616-9.

30. Bagan JV, Jimenez Y, Diaz JM, Murillo J, Sanchis JM, Poveda R, et al. Osteonecrosis of the jaws in intravenous bisphosphonate use: Proposal for a modification of the clinical classification. Oral Oncol. 2009;45:645-6.

31. Marx RE, Sawatari Y, Fortin M, Broumand V. Bisphosphonateinduced exposed bone (osteonecrosis/osteopetrosis) of the jaws: risk factors, recognition, prevention, and treatment.J Oral Maxillofac Surg. 2005;63:1567-75.

32. Ruggiero SL, Drew SJ. Osteonecrosis of the jaws and bisphosphonate therapy. J Dent Res. 2007;86:1013-21.

33. Silverman SL, Landesberg R. Osteonecrosis of the jaw and the role of bisphosphonates: a critical review. Am J Med. 2009;122:S33-45.

34. Marx RE, Cillo JE Jr, Ulloa JJ. Oral bisphosphonate-induced osteonecrosis: risk factors, prediction of risk using serum CTX testing, prevention, and treatment. J Oral Maxillofac Surg. 2007;65:2397-410.

35. Fedele S, Kumar N, Davies R, Fiske J, Greening S, Porter S. Dental management of patients at risk of osteochemonecrosis of the jaws: a critical review. Oral Dis. 2009;15:527-37.

36. Weitzman R, Sauter N, Eriksen EF, Tarassoff PG, Lacerna LV, Dias $\mathrm{R}$, et al. Critical review: updated recommendations for the prevention, diagnosis, and treatment of osteonecrosis of the jaw in cancer patients-May 2006. Crit Rev Oncol Hematol. 2007;62:148-52.

37. Dimopoulos MA, Kastritis E, Bamia C, Melakopoulos I, Gika D, Roussou M, et al. Reduction of osteonecrosis of the jaw (ONJ) after implementation of preventive measures in patients with multiple myeloma treated with zoledronic acid. Ann Oncol. 2009;20:117-20.

38. Ripamonti CI, Maniezzo M, Campa T, Fagnoni E, Brunelli C, Saibene G, et al. Decreased occurrence of osteonecrosis of the jaw after implementation of dental preventive measures in solid tumour patients with bone metastases treated with bisphosphonates. The experience of the National Cancer Institute of Milan. Ann Oncol. 2009;20:137-45.

39. Campisi G, Di Fede O, Musciotto A, Lo Casto A, Lo Muzio L, Fulfaro F, et al. Bisphosphonate-related osteonecrosis of the jaw (BRONJ): run dental management designs and issues in diagnosis. Ann Oncol. 2007; 18:vi168-72.

40. Flichy-Fernández AJ, Balaguer-Martínez J, Peñarrocha-Diago M, Bagán JV. Bisphosphonates and dental implants: current problems. Med Oral Patol Oral Cir Bucal. 2009;14:E355-60.

41. Zahrowski JJ. Bisphosphonate treatment: an orthodontic concern calling for a proactive approach. Am J Orthod Dentofacial Orthop. 2007;131:311-20. 